Please do not remove this page

RMIT

UNIVERSITY

\title{
Is there a crisis of participatory planning?
}

https://researchrepository.rmit.edu.au/esploro/outputs/9921860145301341/filesAndLinks?institution=61RMIT_INST\&index=null

Legacy, C. (2017). Is there a crisis of participatory planning? Planning Theory, 16(4), 425-442.

https://doi.org/10.1177/1473095216667433

Document Version: Accepted Manuscript

Published Version: https://doi.org/10.1177/1473095216667433

Repository homepage: https://researchrepository.rmit.edu.au

(c) The Author(s) 2016

Downloaded On 2023/04/26 19:54:04 +1000

Please do not remove this page 
Thank you for downloading this document from the RMIT Research Repository.

The RMIT Research Repository is an open access database showcasing the research outputs of RMIT University researchers.

RMIT Research Repository: http://researchbank.rmit.edu.au/

\section{Citation:}

Legacy, C 2017, 'Is there a crisis of participatory planning?', Planning Theory, vol. 16, no. 4, pp. 425-442.

See this record in the RMIT Research Repository at:

https://researchbank.rmit.edu.au/view/rmit:45664

Version: Accepted Manuscript

\section{Copyright Statement:}

(C) The Author(s) 2016

Link to Published Version:

https://dx.doi.org/10.1177/1473095216667433 
Title: Is there a crisis of participatory planning?

\title{
Crystal Legacy
}

\begin{abstract}
The critical literature on participation warns that a focus on "consensus" evades the political in planning preventing citizens from confronting and challenging discourse and prevailing orthodoxy about the way the urban ought to be constituted. These critiques raise important questions about the efficacy of participatory planning and its political formation. Moreover, the extent to which citizen's participation can ever challenge dominant trajectories has reached a point of conceptual 'crisis'. In this article I explore the different ways in which participation manifests from the politicising participatory moments in planning. Examining a single case study in Melbourne, Australia, I draw upon 15 key informant interviews with community campaigners who mounted a successful campaign to defeat the controversial East West Link road project. By examining the formal and informal political manifestations of participation over a period of two-years, this paper challenges the sentiment that there is a crisis of participatory planning. It shows how decisions to engage the citizenry in prescribed ways induces other manifestations and formations of citizen's participation through politics and how these manifestations garner a pervasive and influential trajectory to reshape participatory planning.
\end{abstract}

Key words: urban politics, participatory planning, urban democracy, Rancière, transport 


\section{Introduction}

Participation in planning is a political act. Expressing discordance with planning proposals that will bear an environmental, social and distributive injustice onto residents can mean that citizen's participation - widely conceived within planning theory as performed across state and non-state landscapes - is politically motivated. Inch (2014) most recently, in his account of growth-led planning in Scotland, foregrounds the political subjectivity of residents as expressed through and in response to calls for citizen's participation in specified moments in the planning process. The motivations that give rise to citizen's participation can differ across actor groups. For those citizens participating outside the formal participatory planning channels their motivation might be to change or stop altogether a planning proposal from being implemented, while for other citizens and groups the intention could be to advocate and lobby for an alternative set of proposals to take shape. But as the technologies of participatory planning continue their ascendency in western planning systems, criticism endures over the deficiencies of the formation of participatory technologies to address power inequities, institutional inertia; to capture the complexity that geographical scale, temporality and political context introduce; and to accommodate more equity-oriented approaches to planning (Sandercock, 1998; Yiftachel et al, 2000; Krumholz, 1996[2003]; 2013). Early on, Arnstein's (1969) characterisation of a Ladder of Citizen Participation showed us the relationship that citizens have with the decision-making process, illuminating how citizen's participation is shaped through different technologies of participatory planning and how it can be co-opted and captured by political interests. More recently, research into communicative, collaborative and deliberative planning practice (Purcell, 2009; 2016; Lennon, 2016; Inch, 2014; Bond, 2011; Ploger, 2004; Hillier, 2003) has cast a critical light onto how consensus is advanced in the efforts to tame antagonistic participation of citizens. Framing the two - antagonistic and consensus-forming planning - as incommensurable renders invisible the fluidity and political formation of participation. 
In this paper I explore the political formation of participatory planning and of citizen's participation and how this formation gains expression through contentious planning spaces. Drawing on Jacques Rancière's polemic relationship between the police (in this case participatory planning as a tool of the planning system) and the political (the participating citizen), I argue that the crisis of participation that Monno and Khakee (2012) articulate is a misnomer that fails to consider the political formation of participation and how it is forged through particular political and institutional settings. Through a single case study of the controversial East West Link inner city road tunnel in Melbourne, Australia, this paper draws on 15 in-depth interviews with select community campaigners in opposition to the project, including campaigner's accounts of the processes as presented in the 2016 documentary film Tunnel Vision and the monograph titled Beating the Big End of Town: How a community defeated the East-West toll road (Main, 2015), as well as in-depth analysis of news media, social media and policy document analysis and observations from street protests, panel discussions and public hearings occurring between November 2013 to November 2015. I use this data to show how a narrow administration of participatory planning (in this instance, by a State government) is a political act to manage the contestation and antagonism which would seek to unsettle the planning process through a series of 'political moments'. These moments include the political formation of participatory planning, the political formation of citizen's participation and the political context which may assist these formations. The first half of the paper critically explores the idea of a crisis of participatory planning as it relates to broader debates about the de-politicisation of planning (Blühdorn, 2013; Boland, 2014; Inch, 2012; Oosterlynck and Swyngedouw, 2010; Swyngedouw, 2014). This is followed by a discussion situating citizen's participation and participatory planning into dialogue. The paper then turns to explore the East West Link case study and through this analysis identifies the multiple ways in which participation was performed politically throughout this case, focusing of three main political moments that transpired over the course of the two-year study period. The paper concludes by considering the 
political formation of participation and how participatory planning as an inherently political act is fluid and can be shaped by the subjectivity of citizen's participation.

\section{Participatory planning in crisis?}

Participatory planning has its ontological foundation embedded in the conceptualisation of collaborative planning (Healey, 1997), deliberative planning (Forester, 1999) and communicative rationality (Innes and Booher, 2010) through which calls for a more inclusive and enlarged account of what should constitute planning knowledge was embraced (Legacy, 2010). Concerned that an attention on consensus formation renders invisible power relations and structures of inequality this literature which has been developed through an engagement with Mouffe's (1999) agonistic pluralism and captured through the development of agonistic planning within planning theory (Mouat et al, 2013; Gunder, 2003) has positioned power, conflict and difference at the centre of the debate in planning theory (Sandercock, 1998; McGuirk, 2001; Hillier, 2003) and drawing to the foreground the political in planning (Yamamoto, 2016; Porter, 2011).

The centrality of the political in planning raises important practical and theoretical challenges about the how the political not only gains expression, but also affects how participation happens. Minimising the impact of antagonism, planners and elected officials may look to the planning system to manage conflict (Inch, 2012). This antagonism may occur in opposition to tightly designed participatory planning processes which manage out contestation and occur through the creation of rigid rules that restrict engagement (March, 2010). It is the democratic characteristics of a planning system which are institutionalised through legislation and formalised through government-led participatory planning processes and practices where the invitation to citizens to 'have their say' may be perceived to be a product of a series of decisions to curtail participation and its influence (Purcell, 2009). But for whom do these formal processes serve (raising questions about representation and how representation is determined) but also how are these processes serving 
communities (and what outcomes they produce) is never always immediately apparent (see Abram, 2000).

Empirical attention given to the mechanics of participatory planning and how citizen's participation interfaces with government decision making has uncovered numerous limits to the transformative potential of citizen participation within the formal institutional processes of planning. Based on this understanding, the development of many 'good practice' participation techniques including largescale town hall meetings (Hartz-Karp, 2005), the use of social media to reach a wider and more diverse range of participants (Kleinhans et al, 2015), and in some Western planning contexts, the popularisation of citizen juries and citizen decision-making panels (Thompson, 2012) have produced fashionable participatory techniques that are perceived by the political elite to be politically palatable forms of community engagement (Legacy et al, 2014). Critiques of these processes draw attention to the ways in which these participatory channels form only part of the planning and decision making environment. Maginn (2007) for instance describes participation as being 'designed in' by governments creating a perception that governments are doing their due diligence to ensure that residents and community-based groups voice their concerns, rather than really transforming how decisions are made and who is involved in making them. But it is the occasional use of these participatory tools by governments that call into question who and what these formal engagement spaces are actually serving.

The crisis of participatory planning alluded to by Monee and Khakee (2012) cautions that participation is used only intermittedly by government, and when used, serves to mask pro-growth logics and build legitimacy for these decisions (Purcell, 2009). We see the crisis of participatory planning manifesting from a perverse interest in consensus-oriented and outcomes-oriented planning that serves a narrow economic growth logic over more challenging questions relating to the equitable distribution and access to critical social and public infrastructure. It is also argued that participatory processes are employed by governments as tools to help legitimise and achieve 
political 'buy-in' for transport, land use or development decisions, that may have already been predetermined by the political executive or do not challenge a dominant planning orthodoxy (Mees, 2011).

The efficacy of deliberative and communicative planning practices has been the subject of much debate by urban planning scholars examining the experience of communicative processes against agonistic forms of planning (Lennon, 2016; Inch, 2014; Mouat et al, 2013; Bond, 2011; Hillier, 2003). In offering one conceptualisation of the postpolitical decision making environment that aims to manage and control the political, Rancière (1992: 60) argues that participation is commonly understood to provide a "solution to the problems of democracy" by masking power, including issues surrounding power inequality amongst participants. Paradoxically, he argues that the ascendency of participation as a state-led proposition is addressing, what Rancière describes as "the problems of the critiques of democracy" (Rancière, 1992: 60); and of the rational tradition of decision-making within public policy (and for the purposes of this argument, urban planning) that limits decision-making to techno-managerial forms of knowledge (Friedmann, 1973).

As Silver et al (2010: 454) espoused, "government or elite efforts to elicit citizen participation are thinly veiled attempts at securing legitimacy for and cooperation with policies already adopted....Consultation co-opts potential opposition and drives a wedge between grassroots leaders and their constituents". Through these events, as Swyngedouw (2008) argues, politics is reduced to policy making through 'imposed' participatory procedures positioning participation as an appendage of the existing system of planning. This assumes that the drivers for participation are set by governments who then summon the public to participate on a carefully prescribed process that requires a certain amount of planning knowledge to be effective (Inch, 2014). This body of critique and dialectical positioning of formal and consensus-oriented practices of participation against the counter-hegemonic forms of agonism have led Monno and Khakee (2012) to declare that there is a 
"crisis of participatory planning" lamenting that citizen participation has lost its transformative potential and critical influence to forge new policy and urban directives.

\section{Participation as politics}

In considering the statement that there is a crisis in participation, it is necessary to look broadly to participation as it occurs beyond the more formalised processes described above. The democratic failures produced by inadequate and ineffective participatory processes that leave citizens feeling marginalised, excluded or undermined can inspire a range of reactions in those citizens. It is here that grassroots community organising (Alinsky, 1972), union and community-based organising (Burgmann and Burgmann, 1998) and insurgent movements of the kind described by (Castells, 1983) and more recently Swyngedouw (2014) challenge dominant trajectories of planning. These political expressions are also examples of citizen's participation in planning. Regardless of whether participation occurs in the form of incommunicable campaigns which Hardt and Negri (2000: 54) describe as less extensive and shorter in duration or more enduring forms of campaigning, these campaigns are driven by change: to stop or seek to advocate for certain planning outcomes, with a concern that formalised and depoliticised participation will subvert planning's democratic credentials.

When participating citizens start to scrutinise the parameters and potentialities of their engagement, this might be cause for those active residents and community-based groups to stepoutside the government provided engagement platforms and to oppose the proposed development (and sometimes even the process) through informal campaigning. Here I draw on the work of Rancière to consider, as well as to problematize, the ways in which participation is conceived as a political and politicising endeavour. In many cases the different manifestations of participation are induced through what Rancière (1992) describes as a 'blending' between the formal (state-led) centre and the informal (citizen-led) periphery. Rancière's use of the word politics stems from his distinction between police (ruling from distribution of qualification, places and competencies), the 
political (power must become political) and politics (the power of the unqualified) (Rancière, 2010: 39). It is through this distinction that representative forms of democracy are conceived and through which it is possible to argue that democracy is not about participation, but instead exists only in the disjunction: participation as a politically inspired subjectivity that is emergent, ever transforming, evolving and reconstituted element of a democracy occurring across informal and formal spaces.

Focusing then on the State's political use of participatory planning, Cohen (1996) and de Souza Briggs (2008) both lament that the State's privileging of consensus-building participatory processes are used to ostensibly enable implementation. The intent is to achieve an outcome, and therefore participatory planning manifests as a tool to support not only the generation of an outcome but the constricted and regimented processes of participatory planning can also serve to prevent any influential challenge of the project by citizens from emerging. Such techno-managerial governance processes where the focus is on delivering a form of infrastructure are problematic. This form of decision making produces what Swyngedouw (2009: 615) describes as a 'scandal of democracy'; what Metzger et al (2015: 13) interprets as the "promise openings and vast possibilities, yet always also ending up in some form of, by necessity, exclusionary arrangements that again close down certain openings to try to steer development onto a specific path towards the future".

This sets up a binary that positions participation either as a flawed consensus-focused deliberative process on the one hand or exercised through radical pluralist democracy on the other (Silver et al, 2010). The former positions citizens as customers of the state (and not as political subjects) and this has been reflected in urban governance arrangements that embrace a managerial ontology (Macleod, 2011). The latter may manifest as a more radical and grassroots form of urban participation where its subjectivity is deeply political (Castells, 1983). Critics argue that consensus based participatory processes evades the political in planning which prevents citizens from challenging public discourse and orthodoxy about the way the urban is constituted and re-created, but also the very basis upon which participation is often constituted and the planning it produces. 
Instead, those passionate and active citizens will seek out alternative, informal spaces outside formal government processes to politicise participation and offer alternative solutions to city challenges.

The following analysis considers the positioning and conceptualisation of the political formation of participation in planning theory across and between the informal and formal spaces where participation is performed. To examine the political formation of participation in planning, the following sections of this paper consider the ways in which participatory planning and citizen's participation seek to re-create and transform each other. Reconceptualising the relationship between participatory planning and citizen's participation as a political relationship through a prism of political interrelationships raises questions on what it means to be an engaged urban citizen in a complex environment of urban planning politics.

\section{The case of Melbourne's East West Link road tunnel}

Participatory planning serves a central purpose in planning policy development, practice and project delivery in Australian cities. Over the last decade or so, metropolitan regions across Australia have experimented with innovative participatory planning processes. Notable examples include the use of large-scale participatory exercises particularly evident in strategic planning including adaptations of the citizen town meeting concept and interest in citizen panels or 'juries' to decide Council budgets (see e.g. City of Melbourne, 2008; City of Port Phillip, 2007). Situating participation as a key tenet of strategic planning processes (Ruming et al, 2014) will ostensibly support the existing statutory arrangements which are steered by legislative requirements. Regarding the latter, citizen participation of the kind typically seen in strategic planning is ad hoc at the stage of statutory planning. In other instances of land use and infrastructure decision-making, participation is confined to public submissions and hearings in response to a proposed development. The efficacy of those submissions however is determined by the respective Minister who sets the project reference design and by extension, the citizen engagement 'brief'. All other participation and engagement with the project proposal is seen to be outside of the remit of the formal process to consider so if there is 
opposition to the entirety of the project that opposition can take form beyond these formal spaces. In most cases governments will adhere to the formal requirements of participation, but occasionally there are projects that arise where the government of the day seeks to expedite and subvert the participatory planning process in anticipation of fierce resident's opposition: the East West Link was one such project.

In 2013 the \$6-8billion East West Link inner city road tunnel was declared a major transport project of state significance by the Liberal-National Coalition government (Victorian Auditor General, 2015: 1). Elected in November 2010 and under considerable public scrutiny for failing to deliver on their major infrastructure commitments to expand urban rail, the government was under pressure to go into the 2014 November election with a major piece of infrastructure under construction (Martin, 2014). To adhere to this tight year-long time-frame, the ascendency of the East West Link occurred in the absence of formal citizen engagement. Instead the project was devised with no public engagement around its elevation to the top of the State's infrastructure priority list or consideration of the different ways in which Melbourne's transport challenges could be addressed. This failure to engage was acutely evident to the residents who would be directly affected by the project, but was within reason for the government to consider in view of favorable legislation supporting the delivery of large urban infrastructure projects in the State of Victoria.

The decision to not open the East West Link proposal to public debate and citizen engagement before announcing the project as the State's top priority infrastructure project prompted considerable consternation across Melbourne. Residents and transport groups cautioned that a costbenefit ratio of less than one, a lack of strategic land use and transport visioning surrounding this project (Dodson et al, 2014), significant infrastructure shortfalls in the expanding western suburbs of Melbourne (Victoria Auditor General, 2013) and capacity issues on the existing heavy and light rail network should result in the full abandonment of this project. In addition to the substantive content related issues surrounding the prioritisation of this project concerned citizens were cautioning that 
the decision making process lacked rigour prompting action by residents, community-based groups and transport academics to expose the deficiencies in the process too. As one campaign website posted, "the East West Link is part of an ugly, anti-democratic 'end game' by the road lobby in the face of public rejection" (Public Transport Users Association, 2015).

Following the announcement to proceed with a contract signing date before the November 2014 election, the state government announced the Comprehensive Impact Statement and accompanying 30 day panel hearing to advise the government on design considerations for the project (LMA, 2014). The public were invited to provide submissions that responded to any unwanted or negative impacts arising from the project's construction and operation that could be avoided, minimised or offset (DTPLI, 2013a). Following the engagement period the independent Assessment Committee, which was appointed by the State Minister for Planning, was tasked with preparing an assessment report that considered "the alignment, design and performance requirements for the project that may be implemented within the project boundary identified... in the CIS" (DTPLI, 2013b). Adhering to the participatory planning requirements as set out by the Major Transport Projects Facilitation Act 2009, citizen's participation would be restricted to the main issues relevant to the project, as determined by the Minister (LMA, 2013), and formalised through a combined three-month public submission and hearing process.

The public hearing period that followed allowed anyone that provided a written submission to deliver a short presentation to the independent panel. Within the parameters of the public hearing process, residents were judiciously responding to the government's invitation to engage with the Comprehensive Impact Statement. In preparation for the public hearing, some directly affected neighbourhoods, through their neighbourhood associations, banned together hiring a lawyer to represent their case. Other residents drew upon expertise available in the community to engage with the engineering questions the project posed, but also with questions about job creation, 
presenting impressive imagery during the hearing process to inspire creative design solutions to the project to minimise community impact, while remaining critical of the process.

Following a nearly 12 month campaign to oppose the East West Link, the newly elected Labor government in late 2014 tore up the contracts to the project to great satisfaction of the campaigners. Direct action campaigner, Anthony Maine in his self-published account of the community-campaign described their campaign as an example of what is possible when "people stand up and fight back against the big end of town" (Maine, 2015: 111). In this book the citizen-led campaign was lauded for directly contributing to the defeat of this controversial project. But as I argue below, the defeat was also attributed to a vulnerable political context that rendered visible the political formation of the participatory planning process.

\section{Participation as politics in transport planning}

Rancière's (1992; 1998) dissensus politics provides a useful analytical framework to expose and consider the political formation and interactions of participatory planning and citizen's participation. Studying the East West Link case and critically engaging the statement by Monno and Khakee (2012) that there is a crisis of participation exposes the political formation of participatory planning and citizen's participation illuminating the political subjectivity of participation and how it is formed. The case of the East West Link illustrates the production and constitutive nature of participation which remains continuously unsettled at the fulcrum of participatory planning (as constituted by state planning processes and legislative requirements) and citizen's propensity to participate and how that energy is formed and gains expression. In the following section, I explore how citizen participation was used in three political moments shaping the outcome of the East West Link project. The first moment considers the State government's decision to centralise decision making and to only engage citizens in accordance with state legislation. The second political moment focuses on the citizen's response to the State government's approach to participation and the efforts of the individual campaigns to politicise the participatory process. Lastly, the third political moment draws attention 
to the wider political context, which in this case was a vulnerable minority state government seeking to retain government, and an opposition government looking to win enough seats to form government.

\section{Political Moment \#1 - Centralising decision making}

Announcing the East West Link project as the top priority for the state government brought to the fore questions about its prioritisation over other necessary and 'worthy' projects (Dodson, 2014). When public investment decisions are made on urban infrastructure, in an environment where little public money is available and infrastructure needs are growing, these decisions become the focus of political agitation, within affected communities, but also across those communities that are left waiting for their desired project to surface to the top of the government's agenda. The State's decision to expedite the process to ensure that contracts were signed before the state election and their decision to reduce opportunities for participation (via the planning systems and also throughout the election campaign) were political decisions by the State to reduce and manage out opposition. Some campaigners described the formal participatory spaces as providing "challenging policy spaces" and there was a recognition that the design of the participatory spaces reflected,

levels of political operations occurring [making it] very hard for the community to break through and get some real traction in that space.... It's really hard with the current government in Victoria. The acting Premier this week said on radio "the road's going to be built, so get over it." It's really hard to engage the current government (Community Campaigner 9).

One of the main concerns about the formal participatory process was the shortening of the public hearing process to accommodate the State government's difficult timeline to see that the contracts were signed before the election. One campaigner described the impact of this decision: 
I think the fact that they've compressed it down - originally it was 6 months and now it is 3 months. Three months is not enough time to look at a big project. They are reducing people to five minutes or otherwise they'd never be able to hear everyone....[Furthermore] its complete crap, they are not assessing the actual proposal and that is the thrust of all of the legal arguments that we had on the first day. That the panel doesn't have the power under the Act to approve a reference design and transfer the approvals to a different design. That is not contemplated in the Act and that will probably be the basis of the legal challenge (Community Campaigner 13)

Another campaigner described how the framing of the project as a 'done deal' early in the consultative period was perceived by some as a strategic move on the part of the State government to dampen the community's protest and prevent it from gaining momentum against this project. Considerable work was embarked upon to overcome the political rhetoric that this project was a 'done deal', as suggested by this campaigner:

We need to dispel the myth that the government has worked so hard to create -and they have done it quite well - which is that it is a 'done deal'. This is the biggest obstacle because if people didn't think it was a done deal I think we would smash this campaign, personally....It's the fact that from the outset, before they built or drilled anything, they said this was a done deal. And they knew full well that when people feel it's a done deal then governments can do whatever the hell they want (Community Campaigner 14).

Facing the prospect that any campaign mounted could not prevent the construction of the East West Link, campaigns still emerged beyond the formal spaces forging alternative spaces for citizen participation.

Political Moment \#2 - Politicising the participatory process 
In the case of the East West Link project and from the perspective of affected citizens and longstanding public transport advocacy groups, there was a crisis of participatory planning. This crisis was ignited by the closing down of avenues for citizen's engagement in an effort to expedite the participatory process limiting citizen's participation to the formal public submissions and hearing. This prompted residents and community groups to respond by using their participation to politicise the project by expressing their will to participate through the formation of local campaign groups.

What occurred in response to the State's decision to embark on a restrictive form of participatory planning was a proliferation of community organised events including neighbourhood meetings, construction of websites, Twitter hashtags, park festivals and even panel discussions where academics and other transport and urban experts (including the author of this paper) were invited to share their insight about the project. These community-designed spaces shadowed the participatory processes that these residents had come to expect from their government (Legacy, 2015). In the quotation below, this campaigner describes how his group designed a public deliberation event to perform as an information sharing platform. The structure of this event and its creation could be seen as a direct response to the secrecy surrounding the East West Link business case.

Given that we are informal we will hold the occasional event. On the $13^{\text {th }}$ [of Feb] we have an event where Graham Currie and John Stone will be speaking. I don't think there is a lot of quality information out there. I think there are a lot of people out there that have this instinctive feeling that public transport is a good idea, or perhaps they are against the East West Link because of its impact, but they don't know enough to say why it's bad or good. Someone may be in favour of public transport and may be dogmatically pushing something like Doncaster Rail because they love this image rather than being able to understand what's going on and make an informed decision. In between these few events that we hold it's also about getting information out there. We have a 
Facebook page and so I'm always on the lookout for information to share to keep the discussion at the forefront of people's minds (Community Campaigner 8).

Such deliberative spaces created by community groups are illustrative of a reformist agenda gaining traction. This is driven by citizen's political subjectivity to speak out against the project and also the processes which governments use to determine transport priorities and to do so through any strategic means citizen's themselves deem appropriate (Purcell, 2016; Forester, 2013; Innes and Booher, 2010). When the government only opens its doors to particular forms of participation, citizen's participation still happens. These processes are constituted by concerned and affected residents who were left out of the process, but who were finding ways to engage intelligently and reflectively with the transport concerns (e.g. congestion, mobility, financing, etc) that the East West Link was ostensibly seeking to address. What is evident is a clear interest to challenge the content and the foundation of decisions that the government conveyed in support of the project.

Political Moment \#3 - Stopping the East West Link through political participation

Despite all efforts to fast track the project and reduce citizen engagement to questions of mitigation and management of negative impacts from the proposed project, state government decision makers still confronted a political landscape of resistance and dissent from interest groups and citizens. While the community campaigners were responding to the narrow remit of the public engagement brief, their participation had to adapt to be 'effective' - which some campaigners described as stopping the project and doing so by changing the discourse on transport alternatives. This required campaigners to be politically savvy (see Legacy, 2015) but to also consider the political context this project was embedded within.

Leading up to the election, the State government existed as a vulnerable first-term minority government. Campaigning in marginal seats located outside the project corridor was a strategy employed by one public transport advocacy group 
Not all public transport users think that building more roads is a mistake so when you think about what it takes to swing a vote on this issue, in some of those marginal seats, it's just a few people who catch the train who could change the government.... We certainly want to focus on outer suburbs of Melbourne where public transport is particularly poor. Many of these areas are also marginal seats. I think support for their regional community groups is really important. That's a very important political space for this campaign (Community Campaigner 10).

Early on in the community campaigns against the East West Link, the Opposition Labor Party communicated their dislike of the project, but stated that they would honor the contracts if signed before the election citing their concern that a cancellation would threaten the state's strong fiscal environment. The State newspaper The Age cited Bill Russell, a former State government advisor (under Labor) and public policy specialist, as saying that "Labor's insistence that cancelling the contract would create an unacceptable sovereign risk was politically expedient....' what's happened in this country is that politicians have misused it to say that you can't alter either a contract or an aspect of the contract, even if it's in the public interest to do so" (Carey, 2014). This same news story reported the Shadow Treasurer as saying "The view we subscribe to is that it's a well-accepted practice that future governments accept and honour contracts signed by previous governments", and the deputy Greens leader retorted saying "Any so-called sovereign risk will be minimised if Labor gives sufficient 'fair warning' of their intention" (Carey, 2014).

Drawing on media reportage and interviews with politically savvy public transport advocacy groups in Victoria, it is revealed that the Greens party in Victoria which had shown considerable strength in previous Federal elections in the inner-city seats of Melbourne, capturing the important seat situated in the City of Melbourne in 2013, posed a significant threat to the Labor Party. With the Green party advocating extensively to stop this project regardless of the contracts being signed or not, and the fear that critical Labor inner-city seats could be lost to the Greens in what was 
perceived to be a very close state election, prompted Labor to finally concede. Just weeks away from the state election and following the signing of the East West Link contracts, the Opposition Labor Government announced that they would tear up the contracts if elected, position the 2014 November election as a referendum on the East West Link:

Mr Andrews [Opposition Labor leader] said. 'This election will be a referendum between Labor's plan for better public transport and Denis Napthine's \$8 billion dud tunnel' (Gordon and Cook, 2014).

This announcement proved fruitful helping to secure Labor's election win in November 2014 giving the new government the mandate to cancel the East West Link project and to reduce the Greens to winning just one seat in the State Parliament's lower house.

Nearly 18 months on, there are several lessons learnt in Victoria around citizen participation. Since the fall of the East West Link project the Labor government has established an infrastructure agency called Infrastructure Victoria tasked with evaluating project proposals with the hope of depoliticising transport planning. In its first year in existence it has embarked upon a 12 month community and stakeholder consultation process to identify priority infrastructure projects for the State. While this process is still in its early stages at the writing of this paper, there are early signals that a different participatory environment - at least within the remit of this independent agency - to give rise to different technologies of participatory planning in transport. This is evidenced by the recent use of citizens juries to produce the State's 30-year infrastructure strategy offering some signs that a more transparent and participatory ethos could be embraced within this agency.

What is evident in this case was the political formation of participatory planning as observed in political moment \#1; the political formation of citizen's participation as illustrated in political moment \#2; and how these two are forged with and by a deeply political context as illuminated by political moment \#3. Campaigners looked for ways to reengage with the decision making processes 
supporting this project by organising deliberative events, public meetings, and community recreational gatherings mirroring formal channels of participation - when those channels are made available. But in doing so, they positioned this participation in line with the political channels available to them to influence the outcome, and possibly transform the trajectory of transport planning in the State (Legacy, 2015). At the same time the participatory methods deployed by the State and their obvious deficiencies politicised the design of this participatory process triggering an antagonistic form of participation beyond these channels. The politicisation is made all the more evident given the juxtaposition with other more inclusive, deliberative examples of participatory planning through the publicisation and celebration of citizen panels and other engagement exercises that surfaced during other local instances of planning. Citizens are coming to demand ongoing inclusive, deliberative and at the very least transparent forms of decision-making.

\section{Conclusion}

I argued in this paper that participation holds a political and formative relationship to participatory planning in western systems of planning. This paper moves beyond questions about whether the ideals of Habermas' (1996) communicative action and Healey's (1997) collaborative planning can be reconciled with Mouffe's (2005) agonistic pluralism (Beaumont et al, 2008: 110). Instead this paper, in a small way, challenges the sentiment that there is a crisis of participatory planning by offering a case study that shows how active residents and community groups are asserting their claim and stake in the political moments that manifest throughout the planning process and in doing so, rendering visible the political formation of participatory planning and citizen's participation. I used the East West Link case study as an illustrative example of how participatory planning is reconstituted and determined through a political process challenging traditional conceptualisations of the subjectivity of participation. It may be that the expression of participation as adopted by residents is itself a form of interventionist planning that emerges when formal participatory planning forums are deemed exclusive to only some selected citizens (e.g. citizens juries), limit the breadth of 
deliberation to within defined parameters, or not available or closed entirely (e.g. as can be the case in techno-managerial governance settings). As such, there is no crisis of participatory planning if the focus shifts to the subjectivity of citizen's participation. This renders visible the agency that citizen's possess to participate, albeit often expressed in non-formal settings and as represented through differentiated understandings of voice, citizenship, power and deliberations (Forester, 2013; Innes and Booher, 2010). As Rancière (1992: 60-1) pontificates, participation is not "the permanent involvement of citizen-subjects in every domain" as potentially secured through legislative settings supporting participatory planning nor is it necessarily "counterpower" - citizen's participation as motivated by an antagonistic lens; to participate in planning materialises through the "continual renewal of the actors and the forms of their actions". In this wording it suggests that there is a more dialectical political relationship at play that is continually shaping, reproducing and reconstituting what is means to participate. That there may be a crisis in participatory planning only strengthens a narrow conception that participation must be provided by the planning system and made available through the participatory planning technologies available. This renders invisible the multiple ways through which questions of marginalisation and access to decision-making processes (Davidoff, 1965) and the presence of power and structural inequalities (Flyvbjerg, 1998; Porter et al, 2016) have been addressed within planning theory and practice, but which have continued to challenge the ontological foundations of planning and of participatory planning. Rancière (1998: 32) remarks, "nothing is political in itself merely because power relations are at work in it. For a thing to be political, it must give rise to a meeting of policy logic and egalitarian logic that is never set up in advance...It is political when it reconfigures the relationships that determine the workplace in relation to the community". The political formation of participation is the product of the dialectical and constitutive relationship that exists between participatory planning and the subjectivity of citizen's participation. By ignoring the political formation of participation and how it shapes planning undermines the progressive potential to reproduce and redefine participatory planning as a situated practice of planning in a western context. 
The case of the East West Link provides an illustration of a kind of reformist and consensus-driven democracy which secures its permanence by "its mobility, its capacity to shift the sides and forms of participation" (Rancière, 1992: 60). Rancière (2006: 71) is critical of State and of democracy and in later texts proscribes "...it is the public activity that counteracts the tendency of every State to monopolize and depoliticize the public sphere" from here we can draw on Rancière to highlight the progressive force of citizen's participation to shape and be shaped by participatory planning. Any attempt to control, manage, subvert citizen's engagement with the city processes that determine their experience of their city will only provide further impetus for ongoing transformation and provide new expressions of a more antagonistic participation beyond the State and what could conceivably be constituted as participatory planning (Purcell, 2016). Drawing upon the analysis of the East West Link case study, this paper illustrates how citizen's participation may evolve in a coevolutionary and responsive fashion with the political contexts it is situated within and also with the form that participatory planning takes on. Adding to the discourse that participation in planning can be formed from opposition or wider social mobilisations, the participation examined in this paper is borne from a concern for the political challenges confronting cities, including the infrastructure deficits that plague cities and questions surrounding who pays to upgrade and build new infrastructure, the impacts of climate change on cities and what and who will be affected. The form of participation discussed in this paper is the kind that is borne as a response to and in concern for the manner through which these challenging decisions about the urban are being made.

In conclusion, it is important to note that the politicisation of the controversial East West Link road tunnel is not unique. Building large-scale urban infrastructure projects is made political due to a combination of factors including complex funding arrangements, the involvement of the private sector and commercial tendering processes. But difficult questions like why one project is selected over another, who will be served (and not served) by a project and how a project addresses important social and environmental goals often captures the attention of the public, especially those residents and community-based groups immediately affected. The East West Link had all of these 
'political' qualities, but what I have tried to show in this paper is how the decisions to engage the citizenry in prescribed ways are an expression of politics that induces a political formation of citizen's participation. But it is how these manifestations garner a pervasive and influential trajectory to reshape the processes of planning where we observe the greatest potential for participation in the planning of cities. 


\section{References}

Abram S (2000) Planning the Public: Some comments on empirical problems for planning theory. Journal of Planning Education and Research 19: 351-357.

Alinsky S (1972) Rules for radicals: A primer for realistic radicals. New York: Random House.

Arnstein, S. (1969) A Ladder of Citizen Participation. Journal of the American Planning Association, 35(4): 216-224.

Beaumont J and Loopmans M (2008) Towards radicalized communicative rationality: Resident involvement and urban democracy in Rotterdam and Antwerp. International Journal of Urban and Regional Research 32(1): 95-113.

Blühdorn I (2013) The governance of unsustainability: ecology and democracy after the postdemocratic turn. Environmental Politics 22(1): 16-36.

Bond S (2011) Negotiating a 'democratic ethos': moving beyond the agonistic-communicative divide. Planning Theory: 161-186.

Boland P (2014) The relationship between spatial planning and economic competitiveness: the 'path to economic nirvana' or a 'dangerous obsession'? Environment and Planning A 46: 770-87.

Burgmann, M., \& Burgmann, V. (1998). Green bans, red union: environmental activism and the New South Wales Labourers' Federation. Sydney: UNSW Press.

Castells M (1983) The city and the grassroots: a cross-cultural theory of urban social movements. Berkeley: University of California Press.

Carey, A (2014) Labor could tear up East West Link contract if it wins election' The Age 18 April 2015, http://www.theage.com.au/victoria/labor-could-tear-up-east-west-link-contract-if-it-wins-election20140417-36uvc.html

City of Melbourne (2008) Future Melbourne: A bold, inspirational and sustainable city. City of Melbourne.

City of Port Phillip (2007) City of Port Phillip Community Plan 2007-2017. Port Phillip 
Cohen J (1996) Procedure and Substance in Deliberative Democracy. In Benhabib S (eds), Democracy and Difference: Contesting the Boundaries of the Political, Princeton: Princeton University Press, pp. 95-119.

Davidoff P (1965) Advocacy and Pluralism in Planning. Journal of the American Institute of Planners 31: 331-338.

de Souza Briggs X (2008) Democracy as problem solving: Civic capacity in communities across the globe, MIT press.

Dodson J Low N Odgers J Hayward D Taylor R Stone J Gleeson B Currie G Legacy C Sturup S (2014) Tunnel vision or world class public transport: How cancelling the East West Link can fund better transport alternatives for Melbourne. Retrieved from Melbourne

DTPLI (2013a) East West Link (eastern section). Comprehensive impact statement, Department of Transport, Planning and Local Infrastructure, State Government of Victoria, Australia.

DTPLI (2013b) EAST WEST LINK (EASTERN SECTION) PROJECT, ASSESSMENT COMMITTEE APPOINTED UNDER SECTIONS 35 AND 235 OF THE MAJOR TRANSPORT PROJECTS FACILITATION ACT 2009 Department of Transport, Planning and Local Infrastructure, State Government of Victoria, Australia. Flyvbjerg B (1998) Rationality and Power: Democracy in Practice. Chicago: The University of Chicago Press.

Forester J (2013) Design confronts politics, and both thrive! Planning Theory and Practice. 14(2): 251-276.

Forester J (1999) The Deliberative Practitioner: Encouraging Participatory Planning Processes. London: The MIT Press.

Friedmann J (1973) Retracking America: A Theory or Transactive Planning. New York: Anchor Press.

Gordon, J and Cook, H (2014) Labor to dump East-West Link if elected, even if contracts are signed' The Age 11 September 2014, http://www.theage.com.au/victoria/labor-to-dump-eastwest-link-ifelected-even-if-contracts-are-signed-20140910-10f46z.html

Gunder M (2003) Passionate planning for the others' desire: an agonistic response to the dark side of planning. Progress in Planning 60(3): 235-319. 
Habermas J (1996) Three Normative Models of Democracy. In S Benhabib (eds), Democracy and Difference: Contesting the Boundaries of the Political. Princeton: Princeton University Press, pp. 2130.

Hardt M and Negi A (2000) Empire. Cambridge: Harvard University Press.

Hartz-Karp J (2005) A Case Study in Deliberative Democracy: Dialogue with the City. Journal of Public Deliberation 1(1): 1-15.

Hillier J (2003) Agon'izing Over Consensus: Why Habermasian Ideals Cannot be 'Real'. Planning Theory 2(1): 37-55.

Healey P (1997) Collaborative Planning: Shaping Places in Fragmented Societies. London: MacMillan Press Ltd.

Inch A (2014) Ordinary citizens and the political cultures of planning: In search of the subject of a new democratic ethos. Planning Theory: 1-21.

Inch A (2012) Creating 'a generation of NIMBYs'? Interpreting the role of the state in managing the politics of urban development. Environment and Planning C: Government and Policy 30: 520-535.

Innes J E and Booher D E (2010) Planning with complexity: An introduction to collaborative rationality for public policy. New York: Routledge.

Kleinhans R Van Ham M and Evans-Cowley J (2015) Using social media and mobile technologies to foster engagement and self-organization in participatory urban planning and neighbourhood governance. Planning Practice \& Research, 30(3), 237-247.

Krumholz, N. (1996, 2003). Equitable approaches to local economic development. In S. Campbell \& S. S. Fainstein (Eds.), Readings in Planning Theory (Second ed., pp. 224-236). Oxford: Blackwell Publishing.

Krumholz, N. (2013). Toward an equity-oriented planning practice in the United States. In N. Carmon \& S. S. Fainstein (Eds.), Policy, Planning, and People: Promoting Justice in Urban Development (pp. 123-140). Philadelphia: University of Pennsylvania Press.

Legacy C (2010) Investigating the knowledge interface between stakeholder engagement and planmaking. Environment and Planning A. 42(11): 2735-2752. 
Legacy C (2015) Transforming transport planning in the postpolitical era. Urban Studies: 1-17.

Legacy C Curtis C and Neuman M (2014a) Adapting the deliberative democracy 'template' for planning practice. Town Planning Review. 85(3): 319-40.

Lennon M (2016) On 'the subject' of planning's public interest. Planning Theory, 1-19.

LMA (2014) About us. Linking Melbourne Authority, Melbourne, Australia. Available at: http://www.linkingmelbourne.vic.gov.au/ about-us (accessed 13 December 2014).

LMA (2013) Notice of public exhibition of Comprehensive Impact Statement, Consultation release, Melbourne

MacLeod G (2011) Urban Politics Reconsidered: Growth machine to post-democratic city? Urban Studies 48(12): 2629-60.

Maginn P (2007) Deliberative Democracy or Discursively Biased? Perth's Dialogue with the City Initiative. Space and Polity 11(4): 331-52.

Main A (2015) Beating the big end of town: How a community defeated the East-West toll road. Melbourne: Lighting Source, Melbourne.

March A (2010) Practising theory: When theory affects urban planning. Planning Theory, 9(2): 108125.

Martin P (2014) 'Napthine versus Andrews, Road versus rail is anything but simple', The Age accessed 14 December 2015, http://www.brisbanetimes.com.au/victoria/victoria-state-election2014/napthine-versus-andrews-road-versus-rail-is-anything-but-simple-20141113-11mj59

McGuirk PM (2001) Situating communicative planning theory: context, power, and knowledge. Environment and Planning A. 33(2):195-217.

Mees P (2011) Who Killed Melbourne 2030? Paper presented at the State of Australian Cities Conference, Melbourne.

Metzger J Allmendinger P and Oosterlynck S (eds) (2015) Planning Against the Political: Democratic deficits in European territorial governance, New York: Routledge.

Mouat C Legacy C March A (2013) The problem in the solution: Testing agonistic theory's potential to recast intractable planning disputes. Urban Policy and Research 31(2): 150-166. 
Monno V and Khakee A (2012) Tokenism or political activism? Some reflections on participatory planning. International Planning Studies 17(1): 85-101.

Mouffe C (2005) On the Political, London: Routledge.

Mouffe C (1999) Deliberative democracy or agonistic pluralism? Social research: 745-758.

Oosterlynck S and Swyngedouw E (2010) Noise reduction: the postpolitical quandary of night flights at Brussels airport. Environment and Planning A 42: 1577-1594.

Ploger J (2004) Strife: Urban Planning and Agonism. Planning Theory 3(7): 71-92.

Porter L (2011) The point is to change it. Planning Theory \& Practice 12(4): 477-480.

Porter L and Barry J (2016) Planning for Coexistence?: Recognizing Indigenous rights through landuse planning in Canada and Australia. New York: Routledge.

Public Transport Users Association (2015) Side letter sign of road lobby's anti-democratic desperation. Public Transport Users Association, Accessed 14 December 2015 http://www.ptua.org.au/2015/02/06/ewlink-side-letter/

Purcell M (2016) For democracy: Planning and publics without the state. Planning Theory, 1-16.

Purcell M (2009) Resisting Neoliberalization: communicative planning or counter-hegemonic movements?. Planning Theory 8(2): 140-65.

Rancière, J. (2010). Dissensus: On politics and aesthetics. London: Continuum International Publishing Group.

Rancière, J. (2006). Hatred of democracy. London: Verso.

Rancière J (1998) Dis-agreement: Politics and Philosophy, London: University of Minnesota Press.

Rancière J (1992) On the shores of politics, London: Verso.

Ruming K and Gurran N (2014) Australian planning systems reform. Australian Planner 51(2): 102-7.

Sandercock, L. (1998). Towards Cosmopolis: Planning for Multicultural Cities. London, U.K: Wiley.

Silver H Scott A and Kazepov Y (2010) Participation in urban contention and deliberation. International Journal of Urban and Regional Research 34(3): 453-77. 
Swyngedouw E (2014) Where is the political? Insurgent mobilisations and the incipient "return of the political”. Space and Polity 18(2): 122-136.

Swyngedouw E (2009) The antinomies of the postpolitical city: In search of a democratic politics of environmental production. International Journal of Urban and Regional Research 33(3): 601-20.

Swyngedouw E (2008) Where is the political? paper presented to AAG, Boston, 16-21 April 2008.

Thompson N K (2012) Participatory budgeting-the Australian way. Journal of Public Deliberation 8(2): 5.

Victorian Auditor General (2013) Developing transport infrastructure and services for population growth areas. Melbourne: Victorian Auditor General.

Yiftachel O and Huxley M (2000) Debating dominance and relevance: notes on the 'communicative turn' in planning theory. International Journal of Urban and Regional Research, 24(4): 907-913.

Yamamoto A (2016) Why agonistics planning? Questioning Chantel Mouffe's thesis of the ontological primacy of the political. Planning Theory: 1-20. 